\title{
In vivo study of wound healing processes in Sprague-Dawley model using human mesenchymal stem cells and platelet-rich plasma
}

\author{
Karina Karina ${ }^{1,2,3,4,}{ }^{*}$, Johannes Albert Biben ${ }^{1}$, Krista Ekaputri ${ }^{1}$, Imam Rosadi ${ }^{2,5}$, lis Rosliana ${ }^{2}$, Irsyah Afini ${ }^{2}$, \\ Tias Widyastuti ${ }^{2}$, Siti Sobariah ${ }^{2}$, Wismo Reja Subroto ${ }^{2}$
}

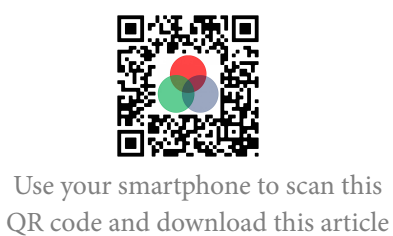

${ }^{1}$ Klinik Hayandra, Yayasan Hayandra Peduli, Jakarta, Indonesia

${ }^{2}$ HayandraLab, Yayasan Hayandra Peduli, Jakarta, Indonesia

${ }^{3}$ Fakultas Kedokteran, Universitas Pembangunan Nasional Veteran Jakarta

${ }^{4}$ Pusat Kajian Stem Cell, Universitas Pembangunan Nasional Veteran Jakarta

${ }^{5}$ Department of Biology, Faculty of Mathematic and Natural Sciences, Mulawarman University, Samarinda, Indonesia

\section{Correspondence}

Karina Karina, Klinik Hayandra, Yayasan Hayandra Peduli, Jakarta, Indonesia

HayandraLab, Yayasan Hayandra Peduli, Jakarta, Indonesia

Fakultas Kedokteran, Universitas Pembangunan Nasional Veteran Jakarta

Pusat Kajian Stem Cell, Universitas Pembangunan Nasional Veteran Jakarta

Email: karina@hayandra.com

History

- Received: Dec 30, 2020

- Accepted: Apr 15, 2021

- Published: Apr 30, 2021

DOI : 10.15419/bmrat.v8i4.670

\section{Check for updates}

\section{Copyright}

(๑) Biomedpress. This is an openaccess article distributed under the terms of the Creative Commons Attribution 4.0 International license.

\begin{abstract}
Background: Mesenchymal stem cells (MSCs) and platelet-rich plasma (PRP) have a potential role in improving wound healing processes. This experimental study aims to compare PRP and MSCs to promote the wound healing process in the animal burn wound model. Methods: PRP from venous blood and MSCs from lipoaspirates were isolated from six donors. Saline solution was used as control while PRP and MSCs as treatment groups were injected to second-degree burn wounds into the backs of 10 male Sprague-Dawley rats for each group. On day-7, 5 rats from each group were euthanized for analyzing VEGF gene, which has roles in angiogenesis. At the end of the study (week 5), the remaining rats were euthanized for histological analysis. Results: The VEGF expression in MSCs and PRP groups was higher than the control group (not significant). The wound healing rate was also faster until 21 days post-burn in the MSCs and PRP groups and getting slowly afterward. Histological analysis showed the burned skin at day 35 had displayed the best differentiation outcome in the MSCs group. In conclusion, human-derived MSCs and PRP do not accelerate epithelialization duration of rats burn wound model. However, they improved wound's vascularization and cell differentiation. Conclusion: MSCs are superior to PRP in enhancing cell differentiation.
\end{abstract}

Key words: mesenchymal stem cells, platelet-rich plasma, VEGF, wound healing

\section{INTRODUCTION}

Mesenchymal stem cell (MSC) therapy has been utilized in many pathological conditions to stimulate tissue regeneration. Depending on the specific medium, MSCs can differentiate into several types of cells ${ }^{1}$. Previous studies reported the benefits of MSCs in the cases of calvarial defects, Crohn's disease, critical limb ischemia, and multiple sclerosis, as well as in enhancement of wound healing ${ }^{2}$. Numerous studies have reported on the efficacy of autologous and allogeneic MSCs in applications to improve the wound healing process in various wound models ${ }^{2-15}$. The effectiveness of MSCs to promote wound healing has also been proven in xenogenic applications ${ }^{16-20}$.

Another well-known modality to improve the wound healing process is platelet-rich plasma (PRP) which contains various growth factors that facilitate the wound healing process ${ }^{21-25}$. PRP has shown excellent results in many in vivo studies as well as in vitro studies related to wound healing ${ }^{21,26-32}$. PRP has also been studied for several clinical conditions, including diabetic foot ulcers, sport soft tissue injuries, and burn wounds, all with encouraging results ${ }^{33-35}$.
The combination of PRP and MSCs can result in further improvement of MSC-mediated wound healing properties $^{36,37}$.

Even though MSCs have shown immense therapeutic benefit and potential, its clinical application is sometimes hindered by regulation issues and high processing costs ${ }^{38}$. Furthermore, in vitro processing and cell amplification have raised safety concerns about the risk of contamination, mutation, and differentiation capacity ${ }^{39,40}$. Therefore, PRP could be an alternative to accelerate wound healing with relatively lower cost and simpler preparation techniques than MSCs. Blood collection in PRP-based therapy would also be more tolerable for critically ill patients than fat-harvesting procedures in autologous MSC preparations. Therefore, sometimes PRP becomes a more feasible option for patients.

Currently, there is limited evidence comparing the therapeutic efficacy of PRP and MSCs as a solitary treatment to improve wound healing. This experimental study aims to compare PRP and MSCs to promote the wound healing process in the animal burn wound model. 


\section{METHODS}

This experimental study was conducted in the Animal Hospital of Bogor Agricultural Institute Facility, in compliance with the protocol, and includes the use of human blood and human tissue that had been reviewed and approved by the Health Research Ethics Committee of the University of Indonesia and Cipto Mangunkusumo Hospital (HREC-FMUI/CMH), with letter no. 625/UN2.F1/ETIK/2016. This study complied with the ARRIVE guidelines and the National Institutes of Health (NIH) guidelines for the care and use of laboratory animals (NIH Publications No. 8023, revised 1978). Contact burn wounds were made on the back of 30 male Sprague-Dawley rats weighing between 100-175 grams. The rats were randomized into three groups: (1) human PRP treatment group, (2) human MSC treatment group, and (3) saline solution treatment group (control). MSCs and PRP were isolated from patients in our medical center. Informed consent was obtained from each patient. The patients underwent stromal vascular fraction (SVF) therapy to treat the various medical conditions described in Table 1.

\section{PRP Preparation}

Blood collection was done using sodium citrate tubes. Four tubes containing $4 \mathrm{~mL}$ of blood were centrifuged at $300 \mathrm{~g}$ for 5 minutes. Plasma was transferred into a new $15 \mathrm{~mL}$ conical tube, and centrifuged at 1000 $\mathrm{g}$ for 5 minutes. The upper layer of plasma was discarded until $5 \mathrm{cc}$ remained at the bottom of the tube, along with the aggregate of the platelet. Platelet and plasma were mixed and activated with calcium activator (H-Remedy). Fibrin-free PRP was treated with the light activation method, as described by the Adistem method. Activated PRP was prepared 1-3 days before application to the wound and stored at $2-8^{\circ} \mathrm{C}$.

\section{MSC Preparation}

Fresh lipoaspirate was obtained from the abdominal fat of human donors. Tissue-dissociation enzyme (H-Remedy) was added to the lipoaspirate in $50 \mathrm{~mL}$ tubes $^{41}$. The mixture was incubated for 1 hour in a $37{ }^{\circ} \mathrm{C}$ incubator. After incubation, low glucose Dulbecco's Modified Eagle's Medium (DMEM; Gibco, Waltham, MA, USA) containing $4 \mathrm{mM} \mathrm{L-glutamine}$ (Gibco) was added to inactivate the enzyme. Tubes containing digested lipoaspirate were centrifuged for 5 minutes at $600 \mathrm{~g}$. Supernatant from each tube was discarded. SVFs in the form of cell pellets were collected, mixed with lysed red cell buffer, and incubated for 10 minutes at room temperature. Afterwards, SVFs were washed twice with phosphate buffered saline (PBS) pH 7.4, and diluted in saline solution. Some of the SVFs were separated for this study and cultured in $25 \mathrm{~cm}^{2}$ flasks with cell density set at 125,000 cells/flask and temperature set at $37^{\circ} \mathrm{C}$. The combination of low-glucose DMEM containing $4 \mathrm{mM}$ L-glutamine supplemented with 10\% FBS (Gibco), $1 \%$ antibiotic-antimycotic solution $(10,000$ units/mL of penicillin, $10,000 \mu \mathrm{g} / \mathrm{mL}$ of streptomycin, and 25 $\mu \mathrm{g} / \mathrm{mL}$ of Amphotericin B) (all from Gibco), and $0.05 \mathrm{ng} / \mathrm{mL} \mathrm{L}$-ascorbic acid was used as the culture medium. The culture medium was replaced every 2-3 days with fresh medium. Cells were sub-cultured after they reached $80 \%$ confluency. Passage 1 MSCs were harvested and stored in saline solution at $4{ }^{\circ} \mathrm{C}$ for $1-3$ days prior to use.

\section{Flow cytometry}

Cell surface marker analysis was performed by flow cytometry (Miltenyi Biotec, Auburn, CA, USA) to confirm the stem cell characteristics of ADSCs. The cell surface markers used were CD73 allophycocyanin (APC), CD90 fluorescein isothiocyanate (FITC), and CD105 peridinin-chlorophyll-protein (PerCP) Cy5.5, as positive MSCs markers. Lineage negative markers and/or positive hematopoietic cells markers included PE-conjugated CD34, CD45, CD11b and CD19, and human leukocyte antigen (HLA)-DR (Becton Dickinson, Franklin Lakes, NJ, USA). The cells $\left(1 \times 10^{5}\right.$, passage 3 ) were stained with fluorescence-labeled probes specific to the cell surface molecule. Data were obtained from 10,000 events per analysis.

\section{Deep Partial Thickness Wound Healing Model and Therapeutic Modality Applica- tion}

The wound healing model by Zhang et al. was used as a reference with minor modifications ${ }^{42}$. The animals were allowed 1 week of an adaptation period. Ketamine $(100 \mathrm{mg} / \mathrm{mL})$ and xylazine $(0.4 \mathrm{mg} / \mathrm{mL})$ were injected into the intraperitoneal space. The back of the rat was shaved and cleaned with povidone-iodine (10\%). A hot flat-round bottom stainless steel (200 g) was placed at the shaved area without pressure to create a deep partial-thickness contact burn wound for 4 seconds. The hot metal had been previously immersed in $100{ }^{\circ} \mathrm{C}$ water for 5 minutes. The heating process was repeated before each application. The rats were randomly assigned to three groups of wound treatment. Each group consisted of 10 rats. Group A received $500 \mu \mathrm{L}$ intradermal PRP injection at the burn wound. Group B received intradermal MSC injection with a total cell count of $4 \times 10^{5}$ cells per rat. 
Table 1: Demographic and medical data of PRP and MSCs donors

\begin{tabular}{ccll}
\hline Donor & Gender & Age & Therapeutic indication \\
1 & F & 75 & Low back pain due to herniated nucleus pulposus \\
2 & F & 45 & Anti aging \\
3 & M & 34 & Autism \\
4 & F & 56 & Metabolic syndrome \\
5 & F & 68 & Anti aging \\
6 & M & 62 & Anti aging \\
\hline
\end{tabular}

Group C received an intradermal normal saline injection and served as the control group. All of the rats received free access to food and water during the 5week observation period.

\section{Wound Healing Analysis \\ Macroscopic evaluation}

All of the wounds were weekly inspected and photographed until the $5^{\text {th }}$ week. Two blinded assessors evaluated the wound surface area by using image analysis software (Image J; National Institute of Health, Bethesda, MD, USA). Percentages of wound areas were calculated by dividing the remaining wound area with the initial wound area.

\section{Real-time analysis of vascular endothelial growth factor (VEGF) expression}

At day 7 , rats ( $\mathrm{n}=5$ from each group) were euthanized. All rats were killed using the cervical dislocation technique. The entire wound and surrounding intact skin were collected and processed to extract the DNA. Rat VEGF was detected and measured by real-time polymerase chain reaction (RT-PCR) method. The primer sequences of VEGF from rats were 5'-GTGTGGTCTTTCGTCCTTCTTA-3' (forward) and 5'-GTTTGTCGTGTTTCTGGAAGTG3' (reverse), while $\beta$-actin primer sequences were used as internal controls and were 5'GTGTGGATTGGTGGCTCTATC-3' (forward) and 5'-CAGTCCGCCTAGAAGCATTT-3' (reverse). Total ribonucleic acid was extracted using QIAamp RNA Blood Mini Kit (Qiagen, Germantown, MD, USA) according to the manufacturer's protocol. Complementary DNA (cDNA) was synthesized from RNA by QuantiTect Reverse Transcription Kit (Qiagen). The resultant cDNA was subjected to quantitative real-time PCR (qPCR) performed using QuantiTect SYBR Green PCR Kit (Qiagen).

\section{Microscopic evaluation}

At the end of the study (week 5), the remaining 14 rats were euthanized using the cervical dislocation technique. One rat from the MSC treatment group died during the trial but the death was considered to be unrelated to the MSC treatment. The entire wound and surrounding intact skin were collected and subjected to histological analysis by hematoxylin-eosin ( $\mathrm{H} \& \mathrm{E})$ staining. Tissue regeneration was analyzed based on re-epithelization and the presence of skin appendages (e.g. hair follicle and sebaceous gland).

\section{Statistical Analysis}

Data analysis was performed using SPSS version 22.0 (IBM Corp., Armonk, NY, USA). One-way ANOVA test and Kruskal-Wallis test were used to analyze the difference of the wound area percentage between groups. The least significant difference (LSD) posthoc analysis was performed when there was a statistically significant difference in the ANOVA test. Wound area closure progression over a period of time was also analyzed by repeated ANOVA. Alpha value was set at 0.05 .

\section{RESULTS}

\section{Cell surface markers}

The cells were confirmed as mesenchymal stem cells due to their expression of differentiation markers CD73, CD90, and CD105 (positive markers). CD45, CD34, CD11b, CD19 and HLA-DR were considered to be negative markers (Figure 1). The expression of CD73, CD90, and CD105 were 99.95\%, 99.79\%, and $98.61 \%$, respectively, while lineanage negative expression (lin negative) was $1.90 \%$.

\section{Wound Healing}

Wound healing rates in the PRP and MSC groups were recorded significantly faster at 21 days post-burn. The 

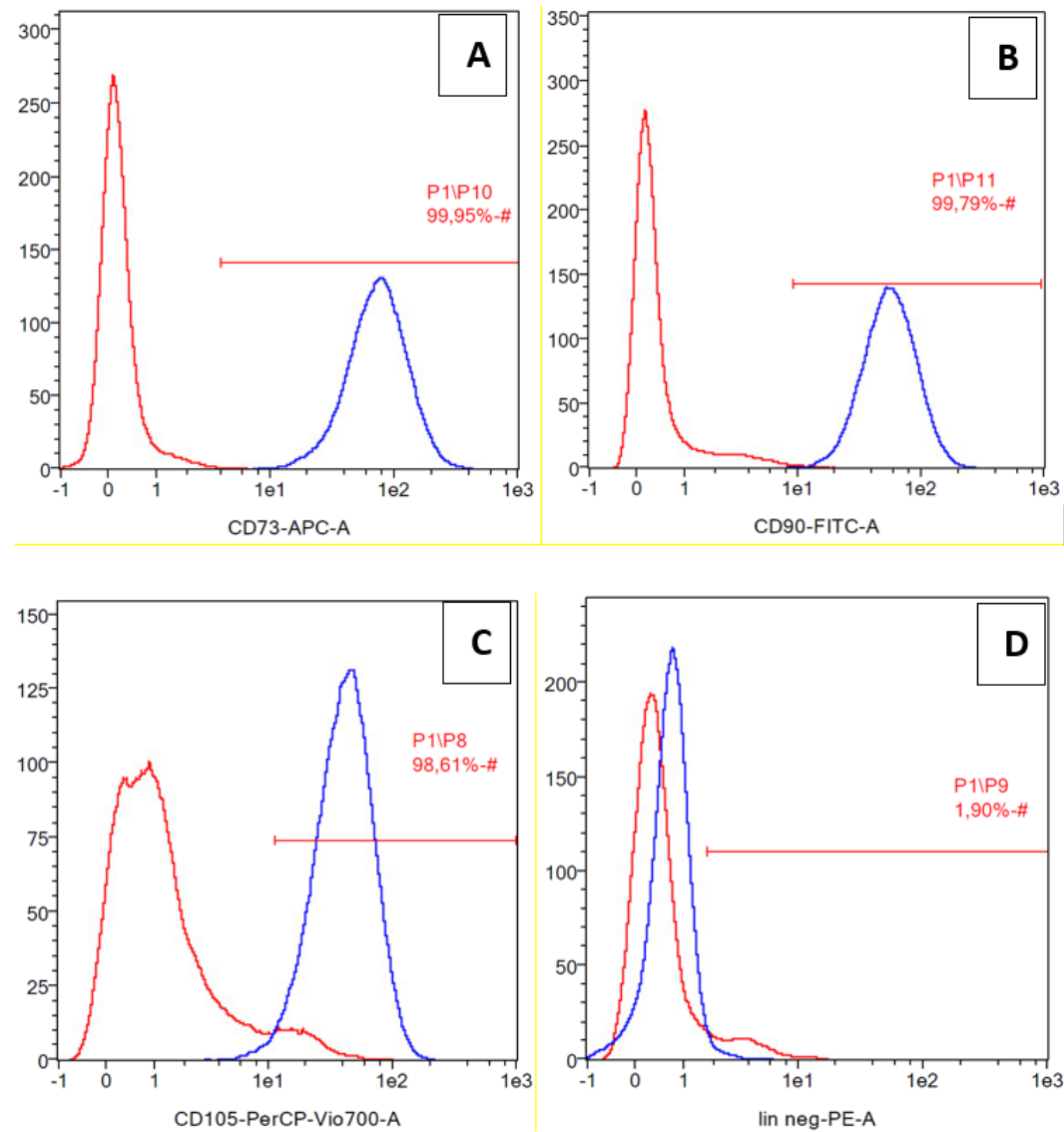

Figure 1: Cell surface marker expression of ADSCs, positive markers were CD73 (A), CD90 (B),CD105 (C) and lineage negative CD45, CD34, CD11b, CD19, HLA-DR (D).

wound closure percentage between groups is summarized in Table 2. PRP and MSC groups showed an increase of wound area at day 7 post-burn. The wound area was reduced afterwards. In the PRP group, a significant size reduction of the initial wound area was detected from day 21 onward ( $p<0.001)$. Similar results were found in the MSC group $(\mathrm{p}=0.026)$. A significant reduction of the initial wound area was detected in the control group from day 28 onward $(\mathrm{p}<$ $0.001)$.

\section{VEGF Expression}

The mean VEGF expression in the MSC and PRP groups was $1.97(\mathrm{p}=0.07)$ and $1.42(\mathrm{p}=0.17)$ times higher than the control group (Figure 2). However, the values were not statistically significant. There was also no statistically significant difference between VEGF expression of the MSC and PRP groups.

\section{Histologic Analysis}

Histological analysis of the burned skin at day 35 showed that all of the groups had developed adequate epithelial lining on the wound surface, dermal connective tissue, and vascular networks. MSCs group displayed the best differentiation outcome since sebaceous glands and fat lobules were also visualized in the tissue sample. These structures were not found in the other two groups (Figure 3).

\section{DISCUSSION}

Rats have unique wound healing characteristics compared to human wound healing. In addition to epithelialization, wounds in the rat model have considerable contraction. The wound contraction is caused by the subcutaneous panniculus carnosus muscle and significant collagen formation (fibrosis) ${ }^{43}$. Wound remodeling phase in rats also begins earlier than in humansat around 6 days ${ }^{44}$. The quicker wound healing phase might also explain the fast wound contraction rate in 


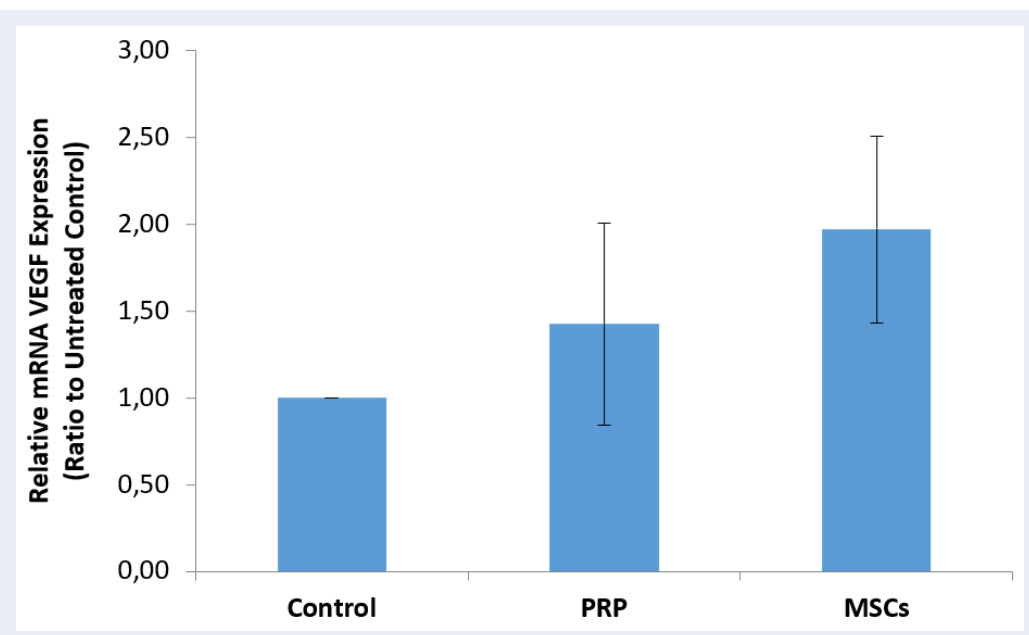

Figure 2: Relative mRNA VEGF expression of MSCs and PRP group (ratio to untreated control).

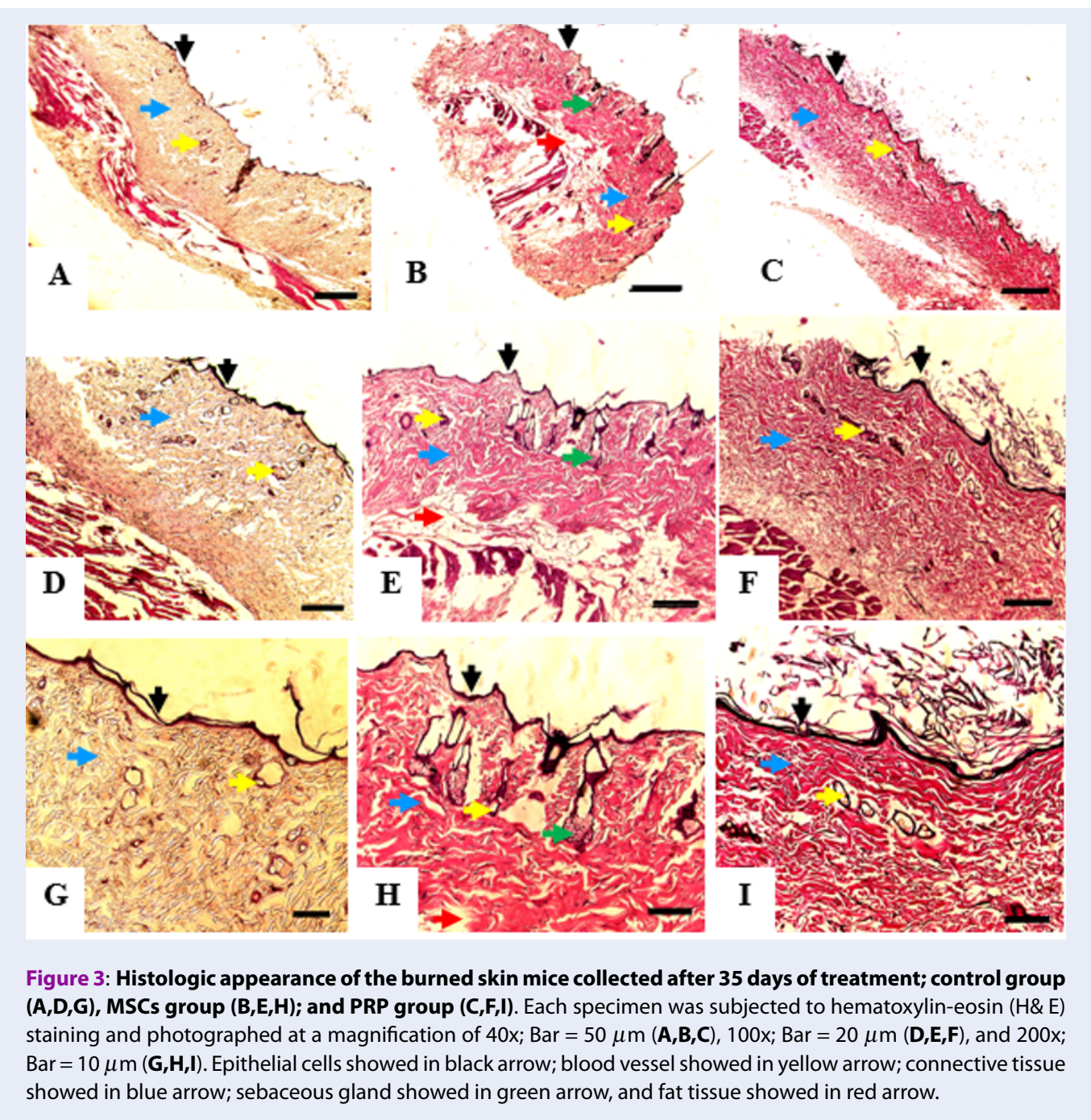


Table 2: Mean of remaining wound size (in percentage) in each intervention group during weekly observation

\begin{tabular}{lcccccc} 
Intervention & Initial & Day 7 & Day 14 & Day 21 & Day 28 & Day 35 \\
PRP & 100 & 115.6 & 92.1 & 47.9 & 17.9 & 7.9 \\
MSCs & 100 & 166.9 & 89 & 50.4 & 21.4 & 11.5 \\
Control & 100 & 98.7 & 87.5 & 86.4 & 14.5 & 1.3 \\
\hline
\end{tabular}

the rat wound model.

Regarding the normal healing time of the rat burn wound model, it mainly depends on the depth of the burn wound. Venter et al. reported that a deep partial-thickness burn wound requires around 35 days to heal while a full-thickness burn wound might require as long as 49 days to be completely epithelialized $^{45}$. Their findings were similar to those in our study, where the burn wounds were almost fully healed by day 35 . Another interesting finding was increased burn wound size in the PRP and MSC treatment groups during observation on day 7 . The increase of burn wound size during the first few days was also reported by Ebrahim et al. and Hyung Woo Ju et al. ${ }^{46,47}$. A possible explanation for the increase could be the separation of eschar from the surrounding vital tissue, causing the wound edge to retract away from the center of the wound. Further studies are needed to elucidate this finding as other similar studies did not report this occurrence.

PRP contains various cytokines and growth factors, such as VEGF, transforming growth factor (TGF)- $\beta$, platelet-derived growth factor (PDGF), and epidermal growth factor (EGF), among others. These cytokines and growth factors promote antiinflammatory responses, angiogenesis, and epithelialization $^{32}$. PRP also influences the formation and organization of collagen fibers, reducing the rate of fibrosis 28,34 .

MSCs improve wound healing by two main mechanisms which are paracrine effect and direct differentiation $^{2,18}$. The paracrine effect of MSCs on wound healing is performed by secretion of various cytokines and growth factors, some of which are similar to those contained in PRP. The role of these cytokines and growth factors are also similar to those of PRP, that is to increase angiogenesis, epithelialization, anti-inflammatory reactions, and antifibrotic effects $6,12,16,19,20$. MSCs can also migrate and differentiate into skin cells, such as dermal fibroblasts and keratinocytes ${ }^{2}$. Xenogenic human-derived MSCs have the potential to enhance wound healing in various animal wound models ${ }^{17-20}$. Liang Xue et al. even reported that xenogenic MSCs could also differentiate into the epidermis in a mouse wound model ${ }^{19}$. Intradermal injection of MSCs and PRP in our study did not seem to shorten epithelialization duration compared to the control group. However, significant wound size reduction was detected earlier on day 21 in these two groups, while it was detected on day 28 in the control group. Previous studies that utilized xenogenic human-derived PRP - either as a single therapy or a combination therapy - showed beneficial effects of PRP on wound healing in animal models ${ }^{48-51}$. The discrepancies might be caused by different PRP preparations, research protocols, and animal species.

Some findings of our study are also different from previous studies that have utilized xenogenic human MSCs. In those studies, MSC application accelerated the epithelialization rate significantly ${ }^{17-20}$. On the other hand, Hanako Doi et al. reported similar results to our study. In their study, xenogenic use of umbilical cord blood derived MSCs and Wharton's jelly derived MSCs did not accelerate wound healing in mice significantly ${ }^{52}$. In their opinion, the xenogenic application of human MSCs produced immunologic and inflammation responses that negated the favorable effect of the MSCs. However, this explanation contradicted the results of other similar studies, which reported that xenogenic application of MSCs to mice and rats produced anti-inflammatory effects ${ }^{19,20}$. In addition, human MSCs have survived in the animal wound environment due to their limited immunogenicity ${ }^{19}$. These differences could be caused by differences in the protocol and animal models across studies.

In our opinion, there is another possibility that might affect the wound healing duration. The anti-fibrotic effects of MSCs and PRP might attenuate the wound contraction phase of wound healing in rats. As discussed earlier, wound contraction is a unique wound closure mechanism that is found in the rat wound healing process. This hypothesis might explain why the wound healing duration in the PRP and MSC treatment groups showed no significant difference 
from that of the control group. This theory is supported by the study conducted by Jia Xian Law et al. ${ }^{48}$; they studied the role of PRP and tissue-engineered skin substitutes to treat full-thickness wounds in a nude mice model. The study found that the application of PRP with or without tissue-engineered skin substitutes reduced the level of myofibroblasts, which plays an essential role in wound contraction ${ }^{48}$. Nevertheless, further studies are needed to elaborate on these findings.

Examining the VEGF messenger ribose nucleic acid (mRNA) level in the wound tissue showed an increase of VEGF expression in the MSC and PRP treatment groups compared to the control group. The elevation of VEGF expression in the MSC group is higher than that for the PRP group. Since PRP does not contain living cells, it is explicable that growth factors will decline over time. Jiro Kurita et al. reported that tissue perfusion improvement was still detected at 4 weeks after PRP treatment ${ }^{23}$. In our study, the level of VEGF in the PRP group was higher than that of the control group at 5 weeks after xenogenic PRP administration. The capacity of growth factors to persist in the tissue is influenced by concentration of the initial growth factors and the ability of live tissue to store the growth factors ${ }^{23}$.

Even though the difference between the VEGF levels in the MSC and PRP groups is not statistically significant, this finding might suggest that humanderived MSCs excite a more sustainable angiogenesis effect than PRP. The high level of VEGF expression on day 35 after applying MSCs also implies that human-derived MSCs were most likely to survive in the wound tissue. However, we did not perform any fluorescence labeling and detection techniques.

Histopathological analysis showed that the wound samples that were treated with MSCs had the best differentiation outcome. The MSCs group developed sebaceous glands and fat lobules that were not detected in the other groups. The blood vessels were found more abundantly in the MSC and PRP groups than in the control group. These results correspond well with the level of VEGF expression that was discussed above. The histopathological findings explain that even though human-derived MSCs and PRP did not improve wound healing duration in the rat burn wound model, the quality of the healed tissue is high in these groups. We are aware of some limitations of our study. The macroscopic wound observations was limited to 35 days which hindered the determination of time needed by the wounds to be epithelialized entirely. The confirmation of MSC survival and differentiation ability could not be confirmed definitively due to the lack of fluorescence labeling.

\section{CONCLUSIONS}

In conclusion, human-derived MSCs and PRP do not accelerate epithelialization duration of burns in the rat burn wound model. However, they improve wound vascularization and cell differentiation. Indeed, MSCs are superior to PRP in enhancing cell differentiation.

\section{ABBREVIATIONS}

cDNA: Complementary DNA

DMEM: Dulbecco's Modified Eagle's Medium

mRNA: messenger ribose nucleic acid

MSCs: Mesenchymal stem cells

PRP: Platelet-rich plasma

RT-PCR: Real-time polymerase chain reaction

SVF: Stromal vascular fraction

VEGF: Vascular Endothelial Growth Factor

\section{ACKNOWLEDGMENTS}

None.

\section{AUTHOR'S CONTRIBUTIONS}

Conception and design: Karina K, I Rosadi, I Rosliana; Administrative support: Karina K; Provision of study material or patients: Karina K; Collection and assembly of data: JA Biben, K Ekaputri, I Rosadi, I Rosliana, I Afini, T Widyastuti, S Sobariah, WR Subroto; Data analysis and interpretation: all authors; Manuscript writing: Karina K, JA Biben, K Ekaputri, I Rosadi, I Rosliana. All authors read and approved the final manuscript.

\section{FUNDING}

None.

\section{AVAILABILITY OF DATA AND MATERIALS}

Data and materials used and/or analyzed during the current study are available from the corresponding author on reasonable request.

\section{ETHICS APPROVAL AND CONSENT TO PARTICIPATE}

Not applicable.

\section{CONSENT FOR PUBLICATION}

Not applicable.

\section{COMPETING INTERESTS}

The authors declare that they have no competing interests. 


\section{REFERENCES}

1. Rosadi I, Karina K, Rosliana I, Sobariah S, Afini I, Widyastuti $T$. In vitro study of cartilage tissue engineering using human adipose-derived stem cells induced by platelet-rich plasma and cultured on silk fibroin scaffold. Stem Cell Res Ther. 2019;10(1):369. PMID: 31801639. Available from: 10.1186/ s13287-019-1443-2.

2. Hassan WU, Greiser U, Wang W. Role of adipose-derived stem cells in wound healing. Wound Repair Regen. 2014;22(3):31325. PMID: 24844331 . Available from: 10.1111/wrr.12173.

3. Karina K, Samudra MF, Rosadi I, Afini I, Widyastuti T, Sobariah S, et al. Stem cell investigation. 2019;6:8. PMID: 31463311. Available from: 10.21037/sci.2019.06.08.

4. Karina K, Rosadi I, Sobariah S, Afini I, Widyastuti T, Rosliana I. Comparable effect of adipose-derived stromal vascular fraction and mesenchymal stem cells for wound healing: an in vivo study. Biomed Res Ther. 2019;6(10):3412-21. Available from: 10.15419/bmrat.v6i10.570.

5. Huang SP, Huang CH, Shyu JF, Lee HS, Chen SG, Chan JY. Promotion of wound healing using adipose-derived stem cells in radiation ulcer of a rat model. J Biomed Sci. 2013;20(1):51. PMID: 23876213. Available from: 10.1186/1423-0127-20-51.

6. Mahmoudian-Sani MR, Rafeei F, Amini R, Saidijam M. The effect of mesenchymal stem cells combined with plateletrich plasma on skin wound healing. J Cosmet Dermatol. 2018;17(5):650-9. PMID: 29504236. Available from: 10.1111/ jocd.12512.

7. Muhammad G, Xu J, Bulte JW, Jablonska A, Walczak P, Janowski M. Transplanted adipose-derived stem cells can be short-lived yet accelerate healing of acid-burn skin wounds: a multimodal imaging study. Sci Rep. 2017;7(1):4644. PMID: 28680144. Available from: 10.1038/s41598-017-04484-0.

8. Chen YW, Scutaru TT, Ghetu N, Carasevici E, Lupascu CD, Ferariu D. The Effects of Adipose-Derived Stem CellDifferentiated Adipocytes on Skin Burn Wound Healing in Rats. J Burn Care Res. 2017;38(1):1-10. PMID: 27893580. Available from: 10.1097/BCR.0000000000000466.

9. Chang YW, Wu YC, Huang SH, Wang HD, Kuo YR, Lee SS. Autologous and not allogeneic adipose-derived stem cells improve acute burn wound healing. PLoS One. 2018;13(5):e0197744. PMID: 29787581. Available from: 10.1371/journal.pone. 0197744.

10. Ahmed HH, Rashed LA, Mahfouz S, Hussein RE, Alkaffas M, Mostafa S. Can mesenchymal stem cells pretreated with platelet-rich plasma modulate tissue remodeling in a rat with burned skin? Biochem Cell Biol. 2017;95(5):537-48. PMID: 28314112. Available from: 10.1139/bcb-2016-0224.

11. Basiouny HS, Salama NM, Maadawi ZM, Farag EA. Effect of bone marrow derived mesenchymal stem cells on healing of induced full-thickness skin wounds in albino rat. Int J Stem Cells. 2013;6(1):12-25. PMID: 24298370. Available from: 10. 15283/ijsc.2013.6.1.12.

12. Formigli L, Paternostro F, Tani A, Mirabella C, Li AQ, Nosi D. MSCs seeded on bioengineered scaffolds improve skin wound healing in rats. Wound Repair Regen. 2015;23(1):115-23. PMID: 25571903. Available from: 10.1111/wrr.12251.

13. Kuo YR, Wang CT, Cheng JT, Kao GS, Chiang YC, Wang CJ. Adipose-Derived Stem Cells Accelerate Diabetic Wound Healing Through the Induction of Autocrine and Paracrine Effects. Cell Transplant. 2016;25(1):71-81. PMID: 25853951. Available from: 10.3727/096368915X687921.

14. Maharlooei MK, Bagheri M, Solhjou Z, Jahromi BM, Akrami M, Rohani L. Adipose tissue derived mesenchymal stem cell (ADMSC) promotes skin wound healing in diabetic rats. Diabetes Res Clin Pract. 2011;93(2):228-34. PMID: 21632142. Available from: 10.1016/j.diabres.2011.04.018.

15. Monteiro BS, Faria RD, Zanella AR, Cruz EP, Godoi NP, Fiorio WA. Mesenchymal stem cell infusion on skin wound healing of dexamethasone immunosuppressed wistar rats. Cienc Rural. 2016;46(10):1824-9. Available from: 10.1590/0103$8478 \mathrm{cr} 20151001$.
16. Caliari-Oliveira C, Yaochite JN, Ramalho LN, Palma PV, Carlos $D$, Cunha FQ. Xenogeneic mesenchymal stromal cells improve wound healing and modulate the immune response in an extensive burn model. Cell Transplant. 2016;25(2):201-15. PMID: 25955320. Available from: 10.3727/096368915X688128.

17. Lee $\mathrm{SH}$, Lee $\mathrm{JH}, \mathrm{Cho} \mathrm{KH}$. Effects of human adipose-derived stem cells on cutaneous wound healing in nude mice. Ann Dermatol. 2011;23(2):150-5. PMID: 21747612. Available from: 10.5021/ad.2011.23.2.150.

18. Pourfath MR, Behzad-Behbahani A, Hashemi SS, Derakhsahnfar A, Taheri MN, Salehi S. Monitoring wound healing of burn in rat model using human Wharton's jelly mesenchymal stem cells containing CGFP integrated by lentiviral vectors. Iran J Basic Med Sci. 2018;21(1):70-6. PMID: 29372039.

19. Xue $L, X u Y B$, Xie JL, Tang JM, Shu B, Chen L. Effects of human bone marrow mesenchymal stem cells on burn injury healing in a mouse model. Int J Clin Exp Pathol. 2013;6(7):1327-36. PMID: 23826413.

20. Liu L, Yu Y, Hou Y, Chai J, Duan H, Chu W. Human umbilical cord mesenchymal stem cells transplantation promotes cutaneous wound healing of severe burned rats. PLoS One. 2014;9(2):e88348. PMID: 24586314. Available from: 10.1371/ journal.pone.0088348.

21. Bir SC, Esaki J, Marui A, Yamahara K, Tsubota H, Ikeda T. Angiogenic properties of sustained release platelet-rich plasma: characterization in-vitro and in the ischemic hind limb of the mouse. J Vasc Surg. 2009;50(4). PMID: 19679427. Available from: 10.1016/j.jvs.2009.06.016.

22. Bertrand-Duchesne MP, Grenier D, Gagnon G. Epidermal growth factor released from platelet-rich plasma promotes endothelial cell proliferation in vitro. J Periodontal Res. 2010;45(1):87-93. PMID: 19602111. Available from: 10.1111/j. 1600-0765.2009.01205.x.

23. Kurita J, Miyamoto M, Ishii Y, Aoyama J, Takagi G, Naito Z. Enhanced vascularization by controlled release of platelet-rich plasma impregnated in biodegradable gelatin hydrogel. Ann Thorac Surg. 2011;92(3):837-44. PMID: 21871267. Available from: 10.1016/j.athoracsur.2011.04.084.

24. González M, Arteaga-Vizcaíno M, Ruiz A, Briceño O, Quintero $\mathrm{M}$, Atencio R. PDGF and VEGF levels in platelet-rich plasma. J Dent. 2014;1(1):16-23. PMID: 25433139. Available from: 10. 12974/2311-8695.2013.01.01.3.

25. Hosny N, Goubran F, Hasan BB, Kamel N. BadrEldin Hasan $B$, Kamel N. Assessment of vascular endothelial growth factor in fresh versus frozen platelet rich plasma. J Blood Transfus. 2015;2015:1-5. Available from: 10.1155/2015/706903.

26. Xian LJ, Chowdhury SR, Saim AB, Idrus RB. Concentrationdependent effect of platelet-rich plasma on keratinocyte and fibroblast wound healing. Cytotherapy. 2015;17(3):293-300. PMID: 25456581. Available from: 10.1016/j.jcyt.2014.10.005.

27. Roffi A, Filardo G, Assirelli E, Cavallo C, Cenacchi A, Facchini $A$. Does platelet-rich plasma freeze-thawing influence growth factor release and their effects on chondrocytes and synoviocytes? BioMed Res Int. 2014;2014:692913. PMID: 25136613. Available from: 10.1155/2014/692913.

28. Jee CH, Eom NY, Jang HM, Jung HW, Choi ES, Won JH. Effect of autologous platelet-rich plasma application on cutaneous wound healing in dogs. J Vet Sci. 2016;17(1):79-87. PMID: 27051343. Available from: 10.4142/jvs.2016.17.1.79.

29. Krašna $M$, Domanović $D$, TomšiA, Švajger $U$, Jeras $M$. Platelet gel stimulates proliferation of human dermal fibroblasts in vitro. Acta Dermatovenerol Alp Panonica Adriat. 2007;16(3):105-10. PMID: 17994170.

30. Okuda K, Kawase T, Momose M, Murata M, Saito Y, Suzuki H. Platelet-rich plasma contains high levels of platelet-derived growth factor and transforming growth factor-beta and modulates the proliferation of periodontally related cells in vitro. J Periodontol. 2003;74(6):849-57. PMID: 12886996. Available from: 10.1902/jop.2003.74.6.849.

31. Han J, Meng HX, Tang JM, Li SL, Tang Y, Chen ZB. The effect of different platelet-rich plasma concentrations on prolifera- 
tion and differentiation of human periodontal ligament cells in vitro. Cell Prolif. 2007;40(2):241-52. PMID: 17472730. Available from: 10.1111/j.1365-2184.2007.00430.x.

32. Ozcelik U, Ekici Y, Bircan HY, Aydogan C, Turkoglu S, Ozen O. Effect of topical platelet-rich plasma on burn healing after partial-thickness burn injury. Med Sci Monit. 2016;22:1903-9. PMID: 27262706. Available from: 10.12659/MSM.895395.

33. Babaei V, Afradi H, Gohardani HZ, Nasseri F, Azarafza M, Teimourian S. Management of chronic diabetic foot ulcers using platelet-rich plasma. J Wound Care. 2017;26(12):7847. PMID: 29244965. Available from: 10.12968/jowc.2017.26.12. 784.

34. Middleton KK, Barro V, Muller B, Terada S, Fu FH. Evaluation of the effects of platelet-rich plasma (PRP) therapy involved in the healing of sports-related soft tissue injuries. lowa Orthop J. 2012;32:150-63. PMID: 23576936.

35. Liu J, Qu W, Li R, Zheng C, Zhang L. Efficacy of autologous platelet-rich gel in the treatment of deep grade II burn wounds. Int J Clin Exp Med. 2018;11(3):2654-9.

36. Kakudo N, Minakata T, Mitsui T, Kushida S, Notodihardjo FZ, Kusumoto K. Proliferation-promoting effect of platelet-rich plasma on human adipose-derived stem cells and human dermal fibroblasts. Plast Reconstr Surg. 2008;122(5):135260. PMID: 18971718. Available from: 10.1097/PRS. 0b013e3181882046.

37. Blanton MW, Hadad I, Johnstone BH, Mund JA, Rogers PI, Eppley BL. Adipose stromal cells and platelet-rich plasma therapies synergistically increase revascularization during wound healing. Plast Reconstr Surg. 2009;123(2):56-64. PMID: 19182664. Available from: 10.1097/PRS.0b013e318191be2d.

38. Heslop JA, Hammond TG, Santeramo I, Piella AT, Hopp I, Zhou J. Concise review: workshop review: understanding and assessing the risks of stem cell-based therapies. Stem Cells Transl Med. 2015;4(4):389-400. PMID: 25722427. Available from: $10.5966 /$ sctm.2014-0110.

39. Sverdlov ED, Mineev K. Mutation rate in stem cells: an underestimated barrier on the way to therapy. Trends Mol Med. 2013;19(5):273-80. PMID: 23481596. Available from: 10.1016/ j.molmed.2013.01.004.

40. Melnik S, Werth N, Boeuf S, Hahn EM, Gotterbarm T, Anton M. Impact of c-MYC expression on proliferation, differentiation, and risk of neoplastic transformation of human mesenchymal stromal cells. Stem Cell Res Ther. 2019;10(1):73. PMID: 30836996. Available from: 10.1186/s13287-019-1187-z.

41. Moegni KF, Rosliana I, Remelia M, Rosadi I, Sobariah S, Afini I. Stromal vascular fraction (SVF) therapy for treatment of various diseases: delivering safety of the first patented SVF tech- nique in Indonesia. Cytotherapy. 2019;21(5):86. Available from: 10.1016/j.jcyt.2019.03.511.

42. Zhang $X$, Wei $X$, Liu L. Increasing burn severity in mice is associated with delayed mobilization of circulating angiogenic cells. Arch Surg. 2010;145(3):259. PMID: 20231626. Available from: 10.1001/archsurg.2009.285.

43. Gottrup F, Agren MS, Karlsmark T. Models for use in wound healing research: a survey focusing on in vitro and in vivo adult soft tissue. Wound Repair Regen. 2000;8(2):83-96. PMID: 10810034. Available from: 10.1046/j.1524-475x.2000.00083.x.

44. Vidinský B, Gál P, Toporcer T, Longauer F, Lenhardt, Bobrov N. Histological study of the first seven days of skin wound healing in rats. Acta Vet Brno. 2006;75(2):197-202. Available from: 10.2754/avb200675020197.

45. Venter NG, Monte-Alto-Costa A, Marques RG. A new model for the standardization of experimental burn wounds. Burns. 2015;41(3):542-7. PMID: 25440857. Available from: 10.1016/j. burns.2014.08.002.

46. Nasiri E, Hosseinimehr SJ, Azadbakht M, Akbari J, Enayati-Fard $\mathrm{R}$, Azizi S. Effect of Malva sylvestris cream on burn injury and wounds in rats. Avicenna J Phytomed. 2015;5(4):341-54. PMID: 26909337.

47. Ju HW, Lee OJ, Lee JM, Moon BM, Park HJ, Park YR. Wound healing effect of electrospun silk fibroin nanomatrix in burnmodel. Int J Biol Macromol. 2016;85:29-39. PMID: 26718866. Available from: 10.1016/j.ijbiomac.2015.12.055.

48. Law JX, Chowdhury SR, Saim AB, Idrus RB. Platelet-rich plasma with keratinocytes and fibroblasts enhance healing of fullthickness wounds. J Tissue Viability. 2017;26(3):208-15. PMID: 28615133. Available from: 10.1016/j.jtv.2017.05.003.

49. Long DW, Johnson NR, Jeffries EM, Hara H, Wang Y. Controlled delivery of platelet-derived proteins enhances porcine wound healing. J Control Release. 2017;253(5):73-81. PMID: 28315407. Available from: 10.1016/j.jconrel.2017.03.021.

50. Han $\mathrm{T}$, Wang H, Zhang YQ. Combining platelet-rich plasma and tissue-engineered skin in the treatment of large skin wound. J Craniofac Surg. 2012;23(2):439-47. PMID: 22421824 Available from: 10.1097/SCS.0b013e318231964a.

51. Bhang SH, Park J, Yang HS, Shin J, Kim BS. Platelet-rich plasma enhances the dermal regeneration efficacy of human adipose-derived stromal cells administered to skin wounds. Cell Transplant. 2013;22(3):437-45. PMID: 23031161. Available from: 10.3727/096368912X656162.

52. Doi H, Kitajima Y, Luo L, Yan C, Tateishi S, Ono Y. Potency of umbilical cord blood- and Wharton ' $s$ jelly-derived mesenchymal stem cells for scarless wound healing. Nat Publ Gr. 2016;2015:1-10. 